\title{
Moving beyond the MSY concept to reflect multidimensional fisheries management objectives
}

Rindorf, Anna; Mumford, John; Baranowski, Paul ; Worsøe Clausen, Lotte; Garcia, Dorleta; Hintzen, N.; Kempf, A.; Leach, Adrian; Levontin, Polina ; Mace, Pamela

Total number of authors:

17

Published in:

Marine Policy

Link to article, DOI:

10.1016/j.marpol.2017.08.012

Publication date:

2017

Document Version

Peer reviewed version

Link back to DTU Orbit

Citation (APA):

Rindorf, A., Mumford, J., Baranowski, P., Worsøe Clausen, L., Garcia, D., Hintzen, N., Kempf, A., Leach, A., Levontin, P., Mace, P., Mackinson, S., Maravelias, C. D., Prellezo, R., Quetglas, A., Tserpes, G., Voss, R., \& Reid, D. (2017). Moving beyond the MSY concept to reflect multidimensional fisheries management objectives. Marine Policy, 85, 33-41. https://doi.org/10.1016/j.marpol.2017.08.012

\section{General rights}

Copyright and moral rights for the publications made accessible in the public portal are retained by the authors and/or other copyright owners and it is a condition of accessing publications that users recognise and abide by the legal requirements associated with these rights.

- Users may download and print one copy of any publication from the public portal for the purpose of private study or research.

- You may not further distribute the material or use it for any profit-making activity or commercial gain

- You may freely distribute the URL identifying the publication in the public portal 


\section{Moving beyond the MSY concept to reflect multidimensional}

2 fisheries management objectives

3

4 Anna Rindorf ${ }^{1 *}$, John Mumford ${ }^{2}$, Paul Baranowski ${ }^{2}$, Lotte Worsøe Clausen ${ }^{3}$, Dorleta García ${ }^{4}$,

5 Niels T. Hintzen ${ }^{5}$, Alexander Kempf ${ }^{6}$, Adrian Leach², Polina Levontin², Pamela Mace ${ }^{7}$, Steven

6 Mackinson $^{8}$, Christos Maravelias ${ }^{9}$, Raúl Prellezo ${ }^{4}$, Antoni Quetglas ${ }^{10}$, George Tserpes ${ }^{11}$, Rüdiger

$7 \quad$ Voss $^{12}$ and David Reid ${ }^{13}$

8

$9 \quad{ }^{1}$ DTU Aqua National Institute of Aquatic Resources, Technical University of Denmark (DTU),

10 Kemitorvet 1, 2800 Lyngby, Denmark.

$11{ }^{2}$ Centre for Environmental Policy, Imperial College London, Silwood Park Campus, Ascot,

12 Berkshire, SL5 7PY, United Kingdom

13 International Council for the Exploration of the Sea, H.C.Andersens Boulevard 44-46, 1553

14 Copenhagen V, Denmark

${ }^{4}$ Azti. Txatxarramendi Ugartea z/g, 48395 Sukarrieta, Spain

${ }^{5}$ Institute for Marine Resources and Ecosystem Studies (IMARES), Wageningen University \&

Research Centre (WUR), P.O. Box 68, 1970 AB IJmuiden, The Netherlands

${ }^{6}$ Thünen Institute of Sea Fisheries, Palmaille 9, 22761 Hamburg, Germany

${ }^{7}$ Ministry for Primary Industries, PO Box 2526, Wellington, New Zealand

${ }^{8}$ Scottish Pelagic Fishermen's Organisation, Heritage House, 135-139 Shore Street,

Fraserburgh, Aberdeenshire, AB43 9BP, UK 
$24{ }^{10}$ Instituto Español de Oceanografía, Centre Oceanogràfic de les Balears, Moll de Ponent, s/n, 2507015 Palma de Mallorca, Spain

$26{ }^{11}$ Hellenic Centre for Marine Research, Institute of Marine Biological Resources and Inland

27 Waters, PO Box 2214, 71003 Heraklion, Crete, Greece

$28{ }^{12}$ Department of Economics, University of Kiel, Wilhelm-Seelig-Platz 1, 24118 Kiel, Germany

$29{ }^{13}$ Irish Marine Institute, Galway

30 *corresponding author, +4535883378, ar@aqua.dtu.dk 


\section{$1 \quad$ Abstract}

2 Maximising the long term average catch of single stock fisheries as prescribed by the globally-

3 legislated MSY objective is unlikely to ensure ecosystem, economic, social and governance

4 sustainability unless an effort is made to explicitly include these considerations. The study

5 investigated how objectives to be maximised can be combined with sustainability constraints

6 aiming specifically at one or more of these four sustainability pillars. It was conducted as a

7 three-year interactive process involving 290 participating science, industry, NGO and

8 management representatives from six different European regions. Economic considerations

9 and inclusive governance were generally preferred as the key objectives to be maximised in

10 complex fisheries, recognising that ecosystem, social and governance constraints are key

11 aspects of sustainability in all regions. Relative preferences differed between regions and cases

12 but were similar across a series of workshops, different levels of information provided and the

13 form of elicitation methods used as long as major shifts in context or stakeholder composition

14 did not occur. Maximising inclusiveness in governance, particularly the inclusiveness of

15 affected stakeholders, was highly preferred by participants across the project. This suggests that advice incorporating flexibility in the interpretation of objectives to leave room for

17 meaningful inclusiveness in decision-making processes is likely to be a prerequisite for stakeholder buy-in to management decisions.

Key words: Sustainability pillars, Inclusive governance, MSY, MEY, MSOY, management objectives, 
1

2 The definition and use of long term targets and limits for fisheries management is at the heart

3 of fisheries science. Defining these is in essence a policy decision and some, such as the

4 Maximum Sustainable Yield (MSY) (UNCLOS 1982), have attained global support. MSY refers to

5 the maximisation of the long-term average landed weight, generally using a specific fishing rate

6 or effort management rule. The concept was originally developed on a single stock basis, and

7 does not explicitly encompass sustainability in wider ecosystem, economic, social and

8 governance contexts (Anderson et al., 2015; Hilborn et al., 2015; Prellezo and Curtin, 2015;

9 Rindorf et al., 2017a). In such multidimensional settings, there are trade-offs between objectives such as catches of predators and their prey (Legovic et al., 2010; Blanchard et al., 2014), catches of individual species caught in mixed fisheries (Dichmont et al., 2008; Hilborn et al., 2012; Ulrich et al., 2017), long term average yield and stability of yield (Smith et al., 2011), and economic yield and social factors such as employment (Kempf et al., 2016). Deciding on these trade-offs is an integral part of defining broader strategic objectives for ecosystem based fisheries management (Garcia et al., 2003).

In jurisdictions where advice has moved beyond the objective of obtaining single species MSY, this has been implemented by, for example, defining limits to fishing on all species to ensure MSY of the least productive species (in the US, Hilborn et al., 2015) or by estimating the maximum economic yield, MEY, across all species (Australia, Dichmont et al., 2010). Other objectives, such as maximising the added value to consumers while ensuring acceptable employment levels, have also been suggested (Methot et al., 2014). Often, potential objectives are defined in scoping exercises involving scientists, managers and other stakeholders, followed by model analyses of the likely consequences of different management measures for performance metrics related to the objectives (Mapstone et al., 2008; Punt et al., 2016; Punt, 2017). The complexity of this decision process can be greatly decreased if the number of tradeoffs which need to decided on can be reduced. Further, complexity and duration of the process 
is highly dependent on the preferences for different objectives expressed by the stakeholders included in the process being both broadly representative of other stakeholders and reasonably stable over time as the development of model scenarios and subsequent discussions take time to complete.

The aim of this study was to investigate how ecological, economic, social, and governmental fisheries management objectives can be consistently addressed in MSY advice. To this aim, the manuscript describes a process through which the most appropriate trade-off can be determined in any specific case and then investigates whether this process provides results which are consistent over time and stakeholder groups. Part of the process is to limit the tradeoff area to only those options considered most relevant by stakeholders, as reducing the number of options that must be considered greatly reduces the complexity of the trade-offs to be considered. Specifically, it was investigated i) whether objectives related to ecosystem, economic, social and governance issues should preferably be addressed as objectives to be maximised or as constraints to be avoided in sustainable management, ii) how the list of objectives and constraints can be limited to reduce the complexity of subsequent discussions by using preferences, iii) whether preferences varied between regions and stakeholder groups, and iv) whether preferences derived using a different method, context and level of detail of the information given were broadly similar to the original scoping exercise. The investigation was based on a three-year study involving scientists, industry, NGOs and managers to investigate preferences in different regions, in different stakeholder groups, in different contexts and based on different levels of detail. The study concludes by discussing the implications of the results for future science, advice and management.

\section{Materials and methods}

While the widely used MSY and MEY concepts suit single species management objectives, the goal of maximsing rarely suits objectives related to multiple and diverse ecosystem, economic, social and governance indicators. Principles such as those of sustainable development (WCED 
1987) are often seen as higher ranking, leading to a situation where objectives maximising for example, yield are not acceptable if they jeopardise sustainability (EU, 2013; Hart, 2013; Rindorf et al., 2017b). Objectives were defined as being related to sustainability where specific ecosystem aspects (such as maintaining forage species and minimising bycatch mortality of potentially endangered or threatened species), economic aspects (such as profitability of fisheries), social aspects (such as employment in the fishery) and governance aspects (such as participation in the decision process) are managed to remain within acceptable limits. The dimensions identifying the limits to this sustainable area were denoted constraints, and objectives for maximisation were discussed only within the sustainable area.

\subsection{Consultation}

The process of consulting and discussing options with stakeholders occurred in three stages aiming at the four scientific aims (i to iv in the introduction):

- A problem framing workshop defining preferred objectives and constraints among categories by region to determine whether preferences differed across regional groups,

- Subsequent reflection workshops to derive perspectives from different stakeholder groups and more detail on preferred objectives, and lastly

- Response workshops to determine whether the objectives originally identified were still seen as relevant when presented to a broader stakeholder group using a different method, context and level of detail of the information given.

In all workshops, stakeholders were identified as scientists, industry, NGOs, or managers depending on their employer (Figure 1).

Figure 1 about here 


\subsection{Regional differences in preference}

The 55 participants in the problem framing workshop conducted in April 2012 were invited partners in the MYFISH project ( $\underline{w w w . m y f i s h p r o j e c t . e u}$ ) or members of organisations associated with the project, including regional advisory councils from all regions, industry representatives, NGOs and managers (Figure 1). Invitations were sent to each organisation and the organisation then selected the most appropriate available attendees. The majority of the organisations were European but participants from New Zealand, Canada and the US were also present. Workshop topic groups focused on identifying a range of potentially relevant objectives and constraints related to alternatives to MSY. The preference for each of these was subsequently ranked on a regional basis in groups encompassing the Baltic Sea, Mediterranean, North Sea, Western Waters and Widely Ranging Stocks, where the latter covers migratory as well as distant water fisheries. Details of the process can be found in the supplementary information. A specially designed graphical tool was used to facilitate option ranking and recording (Kempf et al., 2016, supplementary material). The tool listed the suggested objectives to be considered for maximisation (or minimisation in one case) and the sustainability constraints to that objective derived from the topic groups. Participants were asked to provide ratings $(R)$ for each option and to document the degree of uncertainty or disagreement in the group (U) after group deliberation. Ratings and uncertainty were evaluated following three criteria: i) availability of necessary information, ii) responsiveness of the measure to management, and iii) preference as an objective to maximise or as a sustainability constraint. Priority was given to rating objectives considered for maximisation and, if time permitted, potential constraints to sustainability were also ranked. All groups evaluated objectives at the meeting but constraints were evaluated by only three groups. Remaining constraint evaluations were carried out using questionnaires completed by participants at a later date. This led to a systematic scoring and ranking of options based on the agreed assessment by all the workshop participants. Lastly, the options with the highest preferences were identified for each regional group together with the degree of 
agreement among regional groups, and the overall ranking. The probability for each category of obtaining the observed number of top 5 rankings was estimated using a binomial probability.

\subsection{Perspectives from different stakeholder groups}

The results of the problem framing workshop were presented at two reflection workshops in October 2012 and in February 2013, both with a higher representation of managers than the initial workshop (Figure 1) and both focusing on the Baltic Sea, North Sea and Widely Ranging Stocks. Participants were invited through ICES, regional Advisory Councils and among European and national managers. The workshops were structured as plenary discussions on whether the definitions and preferences indicated in the problem framing workshop seemed appropriate and operational, and on how the objective to maximise inclusive governance (see section 3.1) could be implemented in practice. Views of the participants were gathered in a workshop report by a core group of scientists and the report was circulated to participants for comments.

\subsection{Changes in preferences in response to context and the level of information}

The effect of including a broader stakeholder group and using a different method, context and level of detail of the information given was investigated in six regional response workshops conducted in 2014 (Figure 1). The context of the response workshops differed from the original workshop as a broader range of stakeholders were involved, new key issues to stakeholders had emerged in the two years since the initial problem framing and reflection workshops, quantitative information on the potential trade-offs resulting from the previously expressed preferences was presented, and finally, the consultation method was changed to individual questionnaires. Participants were invited through Advisory Councils and local stakeholder organisations.

Detailed information on the consequences of choosing a specific target, or sets of targets, and management constraints was produced for each of six regions using quantitative statistical models where possible and qualitative models where quantitative models were not available (Voss et al., 2014a; Kempf et al., 2016; Quetglas et al., 2016; Sampedro et al., 2017; García et 
al., 2017). The resulting trade-offs between different ecosystem, economic and social

130 consequences were illustrated using decision support tables (DST) (Kempf et al., 2016). These

131 DSTs visualised model results using graphical tools, such as icon arrays, and were accompanied

132 by a brief description of the model used to derive the underlying data. They included examples of different versions of objectives and constraints.

Preferences were indicated by participants using individual questionnaires, which were completed at the meeting. This approach was used in response to comments at previous workshops that group interactions might affect the results. The questionnaires asked participants to indicate their preferences for each of the scenarios presented (rating, 5 point scale) and how certain they were about their rating (uncertainty; 4 point scale). Finally, there was opportunity for them to give the main reasons for their ratings in free text format on the questionnaire. To enhance comparability with results from the problem framing workshop, the questionnaires were analysed by taking the rating and uncertainty score of individual answers, converting them to distributions approximating the discrete distributions used in the problem framing workshop and then pooling these into a single distribution representing the group similar to those derived in the problem framing workshop. Further details on the workshops can be found in the supplementary material and details on the objectives and constraints rated are given in Tables 1 and 2.

\section{Results}

\subsection{Regional differences in preference} The full list of possible objectives to maximise and sustainability constraints was used for all regional workshops. Suggested objectives and constraints were categorised into the four pillars 

objectives and constraints, the social component had the highest number of proposed options. Average and variation of both rating and uncertainty varied between groups, indicating that a ranking method was preferable to ANOVA or similar analyses.

Social yield was suggested to be difficult to quantify and therefore better addressed through negotiations or constraints rather than maximisation of specific measures. Indicators of stability and resilience were also seen as important constraints in conjunction with other indicators rather than as objectives to be maximised. Some terms were context specific, such as the meaning of 'long term'. In ecosystem considerations, 100 years was considered appropriate, whereas in an economic and social science context much shorter periods were considered long term. Further, stakeholders generally expressed a need to discuss both 'Where to go in the long term?' and 'How to get there in the shorter term?'.

\subsubsection{Objectives for maximisation}

All but six of the indicators were ranked as good or very good by at least one group (Figure 2). The six objectives which ranked as medium or poorer in all regional groups were: Maximise Community Biomass, Maximise Resilience, Maximise Employment on Viable Fishing Units, Maximise Fishing Community Viability, Maximise Social Yield and Maximise Present Yield for Human Consumption. Among the ecosystem and economic objectives, all groups except Widely Ranging Stocks preferred maximising yield in value (economic) to maximising yield in tonnes (ecosystem). Maximise value landed came in the top five ranked of all regions (Table 3 ) except the Baltic Sea and Widely Ranging Stocks where it was ranked sixth and eighth, respectively.

There was a high preference across all regions for economic and governance objectives for maximisation while the social category received poorer ratings (Figure 3). Maximise Inclusive

177 Governance was always highly rated by the groups scoring this objective and economic objectives were in the top 5 in four of the five regions (Table 3, Figure 2). With the exception of 
the Mediterranean, at least one social objective was present in the top 5 in all regions, but the specific objective differed between groups.

Figure 2 and 3 and table 3 about here

Maximise Inclusive Governance, Yield in Value of Key Commercial Species and Yield in Tonnes of Key Commercial Species showed high agreement in scoring between groups with scores of Yield in Value being consistently better than those of Yield in Tonnes in all groups except the Widely Ranging Stocks group. The objectives Minimise Risk of Falling Outside Constraints, Maximise Resource Rent, Maximise Willingness to Invest in Future Fisheries, Maximise Stability, Maximise Employment on Viable Fishing Units, Maximise Catch in Tonnes, Maximise Consumer Welfare and Happiness, and Maximise Fishery Welfare and Happiness showed large differences between regions (Figure 2). Of these, Maximise Resource Rent and Maximise Catch in Tonnes showed the largest difference, both being scored as the highest ranking by one group and lowest by another group.

\subsubsection{Constraints to sustainability}

There were substantial differences between regions on which constraints were preferred (Table 4). In the North Sea and Widely Ranging Stocks the focus was on Good Environmental Status of commercial species, biodiversity, food web functioning and seafloor integrity, and areas with fishing restrictions. While indicators of ecosystem constraints also appeared in the Mediterranean, they were much more dominant in the North Sea and Widely Ranging Stocks where 7 of 12 possible top 5 constraints were related to ecosystems compared to just two of 11 for the Mediterranean. None of the social constraints listed in the Baltic Sea, North Sea and Widely Ranging Stocks regions referred to issues such as small community viability, employment or subsidies. However, such constraints were prioritised highly in the two Mediterranean cases. 
Only one economic constraint was mentioned in the top five of any region (profits Mediterranean Sea). Overall, the economic constraints featured relatively less in the top 5 preferred list than in the list of potential constraints (Figure 4, table 5). Further, there was a higher proportion of constraints related to governance in the preferred list compared to the full list (Figure 4, Table 5).

Table 4 and 5 and figure 4 about here

\subsection{Perspectives from different stakeholder groups}

The first reflection workshop focused on the main priorities for scientific advice on objectives and constraints. The workshop participants felt that scientific advice should recommend ecosystem limits for sustainable exploitation (constraints) on a stock by stock basis. Additionally, participants stated that it was necessary to illustrate the consequences of choices for a wider set of management objectives and that more detailed information on trade-offs would also be useful. Receiving single point advice for all stocks based on, for example, an economic objective was not considered to provide sufficient room for negotiation. Instead, participants preferred to be informed about those trade-offs that fell within the sustainable area. Some participants expressed a preference for limiting the scope of the trade-off scenarios considered solely to those that were sustainable in a single stock and ecosystem context, or would provide solutions that were close to single stock based MSY reference values. Within this 'sustainable and close to objective' range, there could be room for considering other issues, for example negotiations or an inclusive process. Current legislation and governance was seen as an important constraint. The full report is given in ICES (2012).

At the second reflection workshop, the participants concluded that advice should ensure single stock sustainability. Broadly, their conclusions matched those of the previous workshop: 
participants felt that the role of the scientists was to advise on trade-offs between different objectives within the sustainable range and not to determine the exact management measures to be implemented, stating the importance of governance aspects. It was not considered to be the role of scientists to determine the exact trade-offs against, say, economic objectives, although such information can be presented to inform the decision making process. The full report is given in Rindorf et al. (2013).

\subsection{Consistency in preferences}

There was a high correspondence between the initially preferred objectives and constraints and the preferred options in a later context, where more detailed information was provided to a broader group of stakeholders in a later context, in all but two cases (Baltic Sea and Western Waters)(Table 6). While the Baltic Sea workshop showed the same trend as the initial analysis, the response workshop showed only very minor differences in preference between different options. This was presumably linked to the recent collapse of the stock assessment of Baltic cod, which initiated in-depth discussions of the relevance of the quantitative information. In the Western Waters, relative representation by different stakeholder groups was important as representatives of artisanal fleets preferred to be outside the TAC and quota management system and maintain their effort regardless of the objective used to manage the entire fishery. They had no favoured objectives beyond the social constraint to retain status quo effort and employment, while the industrial fleet representatives preferred MEY. As the artisanal fleet representatives were absent in the problem framing workshop, this dichotomy was new to the response meeting. For all objectives, the issues of how the path towards reaching objectives should be designed and the time frame within which this should be achieved were general concerns. At the problem framing workshop, three of the four preferred objectives in the Western Waters group included aspects of fleet economics (Maximise Yield in Value of Key 
255 Fisheries), though Maximise Net Present Value was not among the highest rated indicating a

256 change between the two workshops. An additional comment made at several of the workshop

257 was that even when only the most preferred objectives and constraints were presented, the

258 information presented was highly complex and no single option seemed to satisfy all

259 preferences.

260

261

Table 6 about here 
Through the process implemented in the three workshops, the participants constructed

a list of potential ecosystem, economic, social and governance objectives and constraints, many of which address the shortcomings of the current insular, single-species, single discipline definitions of MSY, while retaining the concept of objectives that are to be maximised within sustainability constraints. Economic objectives were preferred among objectives to be maximised, but were selected less when determining sustainability constraints. Social objectives were given less weight among objectives to maximise. However, the main observation was the overwhelming importance of governance variables, including process attributes, in both objectives and constraints. Preferences for objectives and constraints appeared stable as context, composition of the group and information level changed, except in the case where the stakeholders originally consulted excluded specific groups and in the case where the stock assessment for a major species had suddenly changed dramatically.

Preference was higher for the maximisation of economic objectives compared to maximisation of ecosystem objectives in four of the five regions and no social objective was consistently preferred for maximisation. In contrast, economic constraints were substantially less frequent among the preferred constraints than in the full list. Social constraints appeared in the same proportion in the preferred and the full list while ecosystem constraints appeared in substantially higher proportion in the preferred compared to the full list. Hence, both ecosystem and social constraints were seen as key aspects of sustainability that need to be ensured by setting limitations on the objective of maximising economic yield, and thus in effect receiving precedence over objectives related to maximisation. The preference for economic maximisation objectives over ecosystem maximisation objectives was greatest in areas where species interact and/or different species and sizes are caught in the same fishery, such as the Baltic Sea, North Sea and Western Waters. The value lost by maximising ecosystem objectives such as the total catch in tonnes is particularly large in these regions. Two regions, the Baltic Sea and Widely 
Ranging Stocks, have historically shown large fluctuations in the size of many stocks and an

289

290 objective to minimise risk or maximise stability was scored in the top five in both regions. Though indicators of ecosystem constraints appeared in all regions, they dominated lists of northern region groups, while social sustainability constraints were most important in the Mediterranean in accordance with the results of Voss et al. (2014b). Maximising Inclusive Governance was highly preferred in all regions where this was evaluated (see also Zeller and Pauly, 2004). Similar emphasis was found in a study from South Africa (Hara, 2013). The lack of support for maximisation of social aspects here and elsewhere (Dichmont et al., 2012) may be the result of a lack of history with these indicators, or participants' lack of experience with these concepts (McShane et al., 2011; Stephenson et al., 2017), or different sectors having differing social objectives. Another important issue is the role of science in the decision making process. Several participants remarked that deciding on social and economic trade-offs should be left to political negotiations and that the role of scientists should be relegated to making the consequences of these decisions explicitly known (Rindorf et al., 2017a).

The ranking of different objectives was consistent between the initial problem framing and subsequent response workshops as long as no major shift in stakeholder composition or context occurred. This was unexpected, as it was suggested in the problem framing workshop that social objectives may change quickly compared to biological objectives, particularly in an economic downturn, where the focus is often more on short term economic and social priorities than on long term ecosystem objectives (Mardle and Pascoe, 2002). Though absolute ratings differed substantially between workshops, the relative preferences seemed less affected than absolute level.

While the relative preference for different objectives may remain fairly constant, the management measures required to attain ecosystem objectives will vary over time as fisheries selectivity and stock productivities change (Blenckner et al., 2016). Economic objectives such as Maximise Resource Rent reflect changes in both stock productivity and economic factors, such 
as fuel price, whereas social objectives may reflect economic yield and operational management as well as social aspects such as the distribution of welfare within society or public opinion. Hence, the three types of objectives are likely to be highly interdependent as all depend on stock productivity and current and projected stock status.

There was a clear dichotomy between the strong support for inclusive governance and for addressing shortcomings of single species MSY seen in the problem framing and response workshops, and the preference of managers for limiting the scope of any scenarios considered to those that are sustainable and provide close to MSY in tonnes in a single stock context. This difference of opinion seemed to be caused by the perception of the importance of maintaining consistency with current legislation. For example, fishing above the fishing mortality leading to MSY in a single species context for a species otherwise limiting the economic yield is in direct conflict with legislative requirements in some parts of the world (US, 2007; Fisheries and Aquaculture Law, 2013; EU, 2013; Shelton and Morgan, 2014). While the requirement to remain consistent with current legislation limits the number of practically feasible objectives and constraints, it does not eliminate the need to decide how to address all sustainability pillars in management. In this decision, the need for explicit and clear scientific advice on the consequences of different options remains as does the need for an inclusive process.

The need to remain within sustainable limits received far more support in discussions than maximising any one specific objective. It was stressed in all workshops that objectives should only be maximised when also considering sustainability within ecosystem, economic and social contexts. Examples of the "sustainable area" as being the area where all dimensions of sustainability were fulfilled were often mentioned, even though such an area may not always exist (Rindorf et al., 2017a). To facilitate this, most stakeholders opted for the use of ranges rather than point estimates in defining objectives. Providing advice on trade-offs within sustainable 'objective-ranges' was seen as a scientific task and policy makers were tasked with deciding on the exact trade-offs to be made within these ranges. The ranges would allow room 
for discussing economic and social considerations in an inclusive process involving science, industry, NGO and policymaker representatives in an institutionalised format. In Europe, there

342 has been a recent move towards trying to identify objectives as ranges of fishing mortalities providing yields close to MSY (EU, 2014), thereby providing some flexibility in policy decisions (Kempf et al., 2016; Rindorf et al., 2017b).

The workshop process implemented in this study demonstrated broad support among stakeholders for consistently addressing ecological, economic, social, and governmental fisheries management objectives in MSY advice by defining ecosystem and social constraints to management within which yield, economic benefits and inclusive governance can be broadly maximised. The importance of ecosystem and social constraints was widely supported by multiple workshop participants and priority should be given to defining operational indicators of ecosystem, social and governance sustainability to operationalise these aspects, a need which is also percieved from a scientific perspective (Stephenson et al. 2017). Preferences for economic objectives differed between complex interacting fisheries, such as those in the Mediterranean and North Sea, and simpler cases, such as the Widely Ranging Stocks. Preferences appeared to be relatively similar across workshop participants, context, level of detail and elicitation methods used as long as no major shifts in context or participant composition occurred. The ubiquity of inclusive governance as a key objective suggests that there is an urgent need to operationalise this concept, so that it can work even in a complex and slowly reacting management system like the European system (Eliasen et al., 2015). Involving stakeholders in defining objectives and management choices is essential to achieve consensus, buy-in and compliance (Pascoe et al., 2009; Wilson, 2009). Advice that incorporates MSY and MEY concepts into more flexible decision-making frameworks so as to leave room for inclusiveness is likely to be a prerequisite for effective management. 
The authors thank ICES for providing invaluable assistance in the process, participants of all the workshops for keeping an open mind, indulging us in our long work hours and helping to make this study possible, and finally the scientists who provided the documentation of different tradeoffs and embraced the inclusion of stakeholders in their research at an unprecedented level. We also thank J. Holt and C. Potter for elicitation and analytical tools. The research leading to these results has received funding from the European Community's Seventh Framework Programme (FP7/2007-2013) under grant agreement MYFISH number 289257.

\section{References}

Anderson, J. L., Anderson, C. M., Chu, J., Meredith, J., Asche, F., Sylvia, G., Smith, M. D., Anggraeni, D., Arthur, R., Guttormsen, A., McCluney, J. K., Ward, T., Akpalu, W., Eggert, H., Flores, J. , Freeman, M. A., Holland, D. S., Knapp, G., Kobayashi, M., Larkin, S., MacLauchlin, K., Schnier, K., Soboil, M., Tveteras, S., Uchida, H. and Valderrama, D. 2015. The Fishery Performance Indicators: A Management Tool for Triple Bottom Line Outcomes. PLoS ONE 10(5): e0122809. doi:10.1371/journal.pone.0122809ushing

Blanchard, J. L., Andersen, K. H., Scott, F., Hintzen, N.T., Piet, G. and Jennings, S. 2014. Evaluating targets and trade-offs among fisheries and conservation objectives using a multispecies size spectrum model. Journal of Applied Ecology, 51(3): 612-622.

Blenckner, T., Llope, M., Möllmann, C., Voss, R., Quaas, M.F., Casini, M., Lindegren, M., Folke, C. and Stenseth, N.C. 2015. Climate and fishing steer ecosystem regeneration to uncertain economic futures. Proceedings of the Royal Society of London B: Biological Sciences, 282: 1803

Dichmont, C.M., Deng, A., Punt, A. E., Ellis, N., Venables, W. N., Kompas, T., Ye, Y., Zhou, S. and Bishop, J. 2008. Beyond biological performance measures in management strategy 

evaluation - Bringing in economics and the effects of trawling on the benthos. Fisheries Research, 94: 238-250.

392

Dichmont, C. M., Pascoe, S., Kompas, T., Punt, A. E. and Deng, R., 2010. On implementing maximum economic yield in commercial fisheries. PNAS 107(1): 16-21.

Dichmont, C. M., Pascoe, S. D., Jebreen, E. J., Pears, R. J., Brooks, K. J. and Perez, P. 2012. Providing social science objectives and indicators to compare management options in the Queensland trawl planning process. CSIRO. Brisbane. pp. 87.

Eliasen, S. Q., Hegland, T. J. and Raakjær, J. 2015. Decentralising: The implementation of regionalisation and co-management under the post-2013 Common Fisheries Policy. Marine Policy, 62: 224-232.

EU, 2013. Regulation (EU) No 1380/2013 of the European Parliament and of the Council of 11 December 2013 on the Common Fisheries Policy, Amending Council Regulations (EC) No 1954/2003 and (EC) No 1224/2009 and Repealing Council Regulations (EC) No 2371/2002 and (EC) No 639/2004 and Council Decision 2004/585/EC Official Journal of the European Union, Brussels.

EU. 2014. Task Force on multiannual plans. Final report April 2014. Retrieved from http://www.europarl.europa.eu/meetdocs/2009 2014/documents/pech/dv/taskfor/t askforce.pdf on November 1st 2015

Fisheries and Aquaculture Law, 2013. Ley N²0.657. Chile. Modifica en el ámbito de la sustentabilidad de recursos hidrobiológicos, acceso a la actividad pesquera industrial y artesanal y regulaciones para la investigación y fiscalización, la Ley General de Pesca y Acuicultura contenida en Ley No 18.892 y sus modificaciones. 09-Feb-2013

García, D., Prellezo, R., Sampedro, P., Da-Rocha, J. M., Castro, J., Cerviño, S., García-Cutrín, J. and Gutiérrez, M.-J. 2017. Bioeconomic multistock reference points as a tool for 
overcoming the drawbacks of the landing obligation. ICES Journal of Marine Science: Journal du Conseil: 74(2), 511-524. Doi: 10.1093/icesjms/fsw030

416

417

418

Garcia, S. M., Zerbi, A., Aliaume, C., Do Chi, T., Lasserre, G., 2003. The Ecosystem Approach to Fisheries. Issues, Terminology, Principles, Institutional Foundations, Implementation and Outlook. FAO, Rome, p. 71. Fisheries Technical Paper.

Hara, M. M. 2013. Efficacy of rights-based management of small pelagic fish within an ecosystems approach to fisheries in South Africa. African Journal of Marine Science, 35(3): 315-322.

Hart, D. R. 2013. Quantifying the tradeoff between precaution and yield in fishery reference points. - ICES Journal of Marine Science, 70: 591-603.

Hilborn, R., Stewart, I. J., Branch, T. A., and Jensen, O. P. 2012. Defining Trade-Offs among Conservation, Profitability, and Food Security in the California Current Bottom-Trawl Fishery. Conservation Biology, 26: 257-268.

Hilborn, R., Fulton, E. A., Green, B. S., Hartmann, K., Tracey, S. R. and Watson, R. A. 2015. When is a fishery sustainable? Canadian Journal of Fisheries and Aquatic Sciences, 72: 14331441.

Hoefnagel, E., de Vos, B., and Buisman, E. 2015. Quota swapping, relative stability, and transparency. Marine Policy 57: 111-9.

ICES 2012. Report of the Workshop on North Sea and Baltic Sea Multispecies Trade-offs (WKMTrade). ICES CM 2012/ACOM:71. Available from http://www.ices.dk/sites/pub/Publication\%20Reports/Expert\%20Group\%20Report/ac om/2012/WKM-Trade/wkm_trade2012.pdf

Kempf, A., Mumford, J., Levontin, P., Leach, A., Hoff, A., Hamon, K. G., Bartelings, H., Vinther, M., Staebler, M., Poos, J. J., Smout, S., Frost, H., Burg, S., Ulrich, C., and Rindorf, A. 

from the North Sea. Marine Policy, 69: 146-158.

440

441

Legovic, T., Klanjscek, J. and Gecek, S. 2010. Maximum sustainable yield and species extinction in ecosystems. Ecological Modelling, 221(12): 1569-1574.

Mapstone, B.D., Little, L. R., Punt, A. E., Davies, C. R., Smith, A. D. M., Pantus, F., McDonald, A.D., Williams, A. J., Jones, A. 2008. Management strategy evaluation for line fishing in the Great Barrier Reef: Balancing conservation and multi-sector fishery objectives. Fisheries Research, 94: 315-329.

Mardle, S. and Pascoe, S. 2002. Modelling the effects of trade-offs between long and shortterm objectives in fisheries management. Journal of Environmental Management (65): 49-62.

McShane, T. O., Hirsch, P. D., Trung, T. C., Songorwa, A. N., Kinzig, A., Monteferri, B., Mutekanga, D., Thang, H. V., Dammert, J. L., Pulgar-Vidal, M., Welch-Devine, M., Brosius, J. P., Coppolillo, P. and O'Connor, S. 2011. Hard choises: Making trade-offs between biodiversity conservation and human well-being. Biological Conservation, 144: 966-972.

Methot, R. D., Tromble, G. R., Lambert, D. M. and Greene, K. E. 2014. Implementing a sciencebased system for preventing overfishing and guiding sustainable fisheries in the United States. ICES Journal of Marine Science, 71: 183-194.

Mohn, R. K., and Chouinard, G. A. 2007. Harvest control rules for stocks displaying dynamic production regimes. ICES Journal of Marine Science., 64:693-697.

Pascoe, S., Proctor, W., Wilcox, C., Innes, J., Rochester, W. and Dowling, N. 2009. Stakeholder objective preferences in Australian Commonwealth managed fisheries. Marine Policy, 33(5): 750-758. 
Punt, A. E. 2017. Strategic management decision-making in a complex world: quantifying, understanding, and using trade-offs. ICES Journal of Marine Science: Journal du Conseil, 74: 499-510. Doi: 10.1093/icesjms/fsv193.

Punt, A. E., Butterworth, D. S., de Moor, C. L.,De Oliveira, J. A. and Haddon, M. 2016. Management strategy evaluation: best practices. Fish and Fisheries, 17: 303-334.

Prellezo, R., and Curtin, R. 2015. Confronting the implementation of marine ecosystem-based management within the Common Fisheries Policy reform. Ocean \& Coastal Management, 117: 43-51.

Quetglas, A., Merino, G., Ordines, F., Guijarro, B., Garau, A., Grau, A.M., Oliver, P. and Massutí, E. 2016. Assessment and management of western Mediterranean small-scale fisheries. Ocean \& Coastal Management, 133: 95-104.

Rindorf, A, Schmidt, J., Bogstad, B., Reeves, S., and Walther, Y. 2013. Framework for Multispecies Assessment and Management. An ICES/NCM Background Document. Available from http://www.ices.dk/publications/Documents/Miscellaneous\%20pubs/A\%20framework \%20for\%20multispecies\%20assessment\%20and\%20management.pdf

Rindorf, A., Dichmont, C. M. , Levin, P. S., Mace, P., Pascoe, S., Prellezo, R., Punt, A. E., Reid, D. G., Stephenson, R., Ulrich, C., Vinther, M. and Clausen, L. W. 2017a. Food for thought: Pretty good multispecies yield. ICES Journal of Marine Science: Journal du Conseil, 74: 475-486.

Rindorf, A., Cardinale, M., Shephard,S. De Oliveira, J. A. A., Hjorleifsson, E., Kempf, A., Luzenczyk,A., Millar, C., Miller, D. C. M., Needle, C. L., Simmonds, J., and Vinther, M. 2017b. Fishing for MSY: using "pretty good yield" ranges without impairing recruitment. ICES Journal of Marine Science: Journal du Conseil, 74: 525-534. 
Sampedro, P., Prellezo, R., García, D., Da-Rocha, J. M., Cerviño, S., Torralba, J., Touza, J., GarcíaCutrín, J., and Gutiérrez, M. J. 2017. To shape or to be shaped: engaging stakeholders in fishery management advice. ICES Journal of Marine Science: Journal du Conseil, 74(2): 487-498.

Shelton, P. A., and Morgan, M. J. 2014. Impact of maximum sustainable yield-based fisheries management frameworks on rebuilding North Atlantic cod stocks. Journal of Northwest Atlantic Fishery Science, 46: 15-25. doi:10.2960/J.v46.m697

Smith, A.D., Brown, C.J., Bulman, C.M., Fulton, E.A., Johnson, P., Kaplan, I.C., Lozano-Montes, H., Mackinson, S., Marzloff, M., Shannon, L.J. and Shin, Y.J., 2011. Impacts of fishing low-trophic level species on marine ecosystems. Science, 333(6046), pp.1147-1150.

Stephenson, R. L., Benson, A. J., Brooks, K., Charles, A., Degnbol, P., Dichmont, C. M., Kraan, M., Pascoe, S., Paul, S. D., Rindorf, A., and Wiber, M. (2017). Practical steps toward integrating economic, social and institutional elements in fisheries policy and management. ICES Journal of Marine Science, doi:10.1093/icesjms/fsx057.

US 2007. Magnuson-Stevens Fishery Conservation Management Reauthorization Act of 2006. Public Law, 479.

Ulrich, C., Vermard, Y., Dolder, P. J., Brunel, T., Jardim, E., Holmes, S. J., Kempf, A., Mortensen, L. O., Poos, J.J. , and Rindorf, A. (2017). Achieving maximum sustainable yield in mixed fisheries: a management approach for the North Sea demersal fisheries. ICES Journal of Marine Science, 74: 566-575.

Voss, R., Quaas, M. F., Schmidt, J. O., and Hoffmann, J.2014a. Regional trade-offs from multispecies maximum sustainable yield (MMSY) management options. Marine Ecology Progress Series, 498: 1-12. 
509 Voss, R., Quaas, M. F., Schmidt, J. O., Tahvonen, O., Lindegren, M. and Mollmann, C. 2014b.

510 Assessing Social - Ecological Trade-Offs to Advance Ecosystem-Based Fisheries

$511 \quad$ Management. PLoS ONE 9(9).

512 Wilson, D. C. 2009. The paradoxes of transparency: science and the ecosystem approach to

513 fisheries management in Europe (Vol. 5). Amsterdam University Press, Amsterdam.

$514 \quad 304 \mathrm{pp}$.

515 WCED 1987. Our Common Future. Oxford: Oxford University Press. p. 27. ISBN 019282080X.

516 Zeller, D. and Pauly, D. 2004. The future of fisheries: From 'exlusive' resource policy to inclusive public policy. Marine ecology progress series, 274: 295-298. 


\section{Workshop process, initial problem framing workshop}

520 In the first part of the problem framing workshop, participants were divided into four different

521 topic groups according to their stated individual preferences to identify possible objectives and

522 constraints. Each group focused on one of the following: ecosystem issues, stock interaction

523 issues, economic issues and social and governance issues. In the topic groups different objectives for maximisation were discussed and a consensus was reached on those to be evaluated further. The number of participants in the groups ranged from 11 to 18 . Scientists tended to join the group covering their area of expertise. NGOs were only represented in the groups on ecosystem issues and stock interaction issues. Industry representatives were present in all groups but mostly attended the economic and social and governance groups. The groups were asked to focus on three questions: 'What can/should we maximise?', 'What should we sustain?' and 'How can we implement it?'.

The second part of the initial problem framing workshop determined which objectives and constraints were considered relevant and desirable in different regions. This was conducted in regional groups encompassing the Baltic Sea, Mediterranean, North Sea, Western Waters and Widely Ranging Stocks, where the latter covers migratory as well as distant water fisheries. Evaluations were based on a five point scale from "very good" to "very poor", and uncertainty or disagreement within the group was reflected in a distribution of scores. Group rapporteurs included text comments in the spreadsheets explaining group decisions. The ratings were integrated into a distribution of "utility" for each objective and constraint using a matrix method. The matrix method operates on discrete distributions in a way that is mathematically consistent with an intuitive interpretation of how distributions should be related. For example,

542 'low' feasibility and 'low' impact should lead to a distribution for the utility probability mass concentrated around the 'low' end of the scale. The method is described fully in Holt et al. 
544 (2014). The options were subsequently ranked primarily on expected utility values with

545 uncertainty as a secondary ranking criterion, if utility values were the same.

546

547 Figure S1 about here

548

549

Description of regional response workshops

550

Baltic Sea

551 Baltic Sea stakeholders were consulted through the Baltic Sea Advisory Council, at a workshop

552 in June 2014 (Figure 1). The effects on yield and ecological, economic and social sustainability of

553 three different objectives were demonstrated in a DST: Maximise Net Present Value (Economic),

554 Maximise Net Present Value While Conserving Sprat (Economic with ecosystem constraints) and

555 Maximise Net Present Value While Conserving Equity between Countries (Economic with social

556 constraints).

557

558

Eastern Mediterranean: Aegean Sea

559 Scenarios for the Aegean Sea were presented and discussed during the annual meeting of the

560

Pan-Hellenic Union of Middle-Range Ship Owners in June 2014 (Figure 1). The series of

561 objectives examined included the current single species MSY (Ecosystem), Maximise Net Present

562 Value (Economic) and a scenario which went towards MEY but limited the reduction of fleet capacity (Economic with social constraints).

564

A workshop was organized in January 2014 with the participation of fishermen and representatives from fisheries managers (Figure 1). The set of objectives examined included the 
569 intermediate scenario in between these two previous, extreme situations in which the effort, 570 catch and economic value are at the average between the current and the predicted MEY 571 scenarios (Economic with social constraints).

North Sea

574 The stakeholder workshop for the North Sea case study was held in July 2014 together with the

575 North Sea Advisory Council demersal fisheries group (Figure 1). Three different cases were 576 discussed. The first focused on biological interactions in the context of multispecies MSY in 577 tonnes (Ecosystem), value (Economic) and multispecies ranges (Ecosystem and Governance).

578 The second focused on MSY in tonnes (Ecosystem) and net present value (Economic) when

579 accounting for technical interactions in the fisheries on North Sea gadoids while implementing 580 single species $\mathrm{F}_{\mathrm{MSY}}$ and a landing obligation. The third focused on multispecies MSY in tonnes 581 (Ecosystem) and net present value (Economic) for flatfish and shrimp fleets in the southern 582 North Sea in an ecosystem setting.

Western Waters

585 The stakeholder workshop was held for the Iberian Sea case study in conjunction with a regular 586 meeting of the South Western Waters Advisory Council in June 2014 (Figure 1). Two objectives 587 were presented, single stock MSY (Ecosystem) and Maximise Net Present Value of key commercial species (Economic). These two objectives were combined in scenarios with constant effort in artisanal fleets, as a proxy for maintaining the employment in these fleets (adding social constraints). 
593 A stakeholder workshop was organized in February 2014 together with the Pelagic Advisory 594 Council (Figure 1). Two issues played a large role at the workshop: firstly, an important ad-hoc 595 meeting on Mackerel TAC distribution was scheduled just prior to the workshop resulting in a 596 lower attendance of industry members and secondly, the interpretation of MSY under a landing 597 obligation varied considerably among participants. Case-studies focused on Norwegian Spring 598 Spawning herring, North Sea herring and North Sea sprat and tuna in the Indian Ocean. Results 599 for MSY (Ecosystem), Stability of Catches (Ecosystem) and Good Environmental Status of the 600 stocks (Ecosystem) were presented for the North Sea stocks. Alternatives for Tuna in the Indian 601 Ocean were presented at an IOTC meeting in November 2014 where mixed-fisheries MSY was 602 the main point of discussion. 


\section{7 . Figure captions}

2 Figure 1. Total (number) and composition (bars) of participants in the workshops.

3 Figure 2. Graphic summary of overall average means and range of means for different

4 objectives by different regional groups. Objectives that were evaluated by fewer than three

5 regional groups are not included.

6 Figure 3. Average rating of objectives in the different categories by regional groups ordered

7 from no interaction (left) to high interaction (right) between yields of different fisheries. Bars

8 indicate rating average and vertical lines show the range of ratings observed in that category.

9 Figure 4. Distribution of objectives to be maximised and constraints to limit sustainability 10 across sustainability pillars on the full list (options) and the top five selected in regional groups.

11 Figure S1. Graphical tool to record ratings. Four evaluations are shown. The bottom right panel

12 represents medium desirability with high uncertainty or disagreement. For the other panels,

13 the evaluation ranges from "very good" (top left), "medium" (top right), to "very poor"

14 (bottom left), each with very little uncertainty or disagreement 


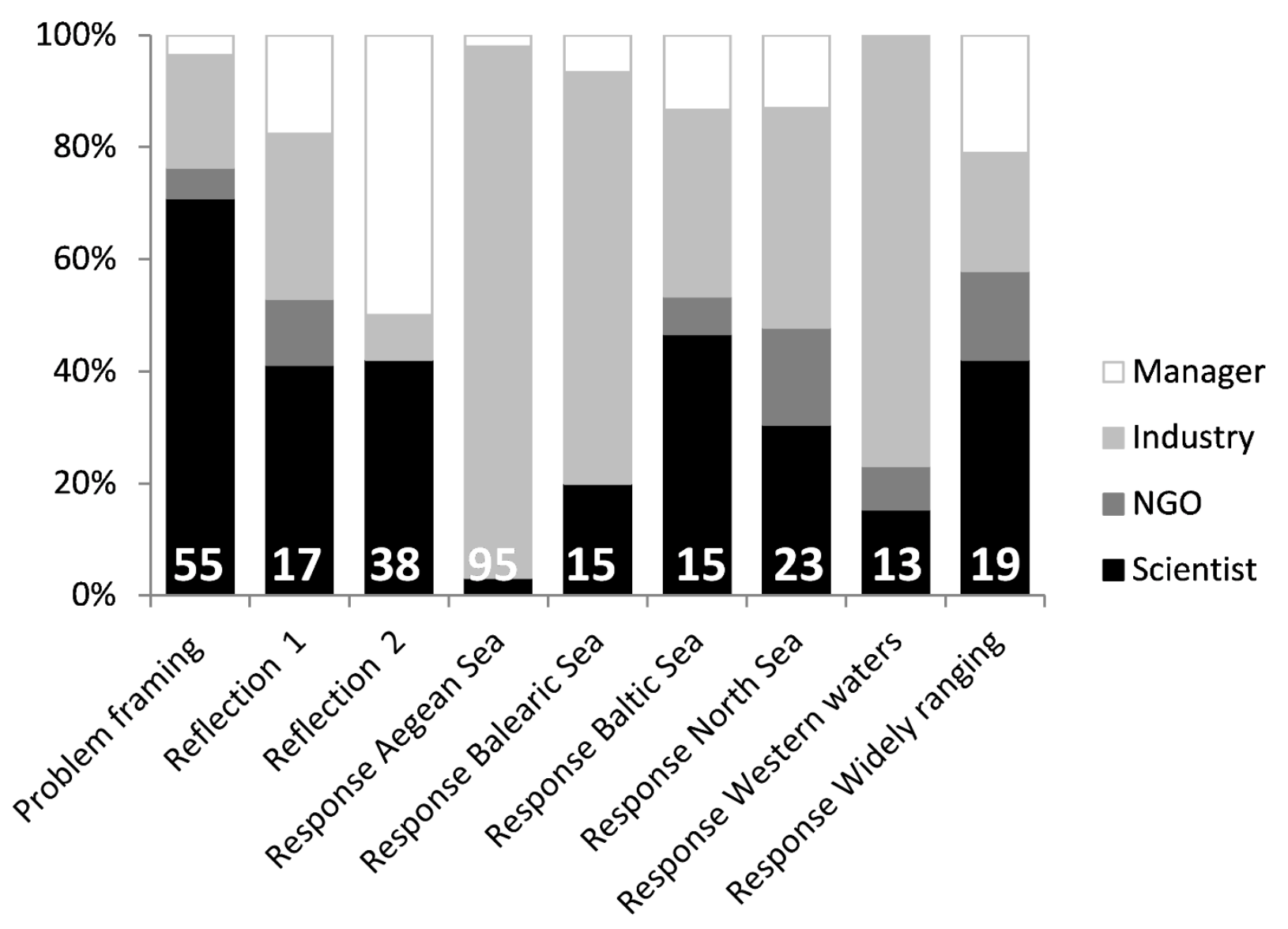

Fig.1 


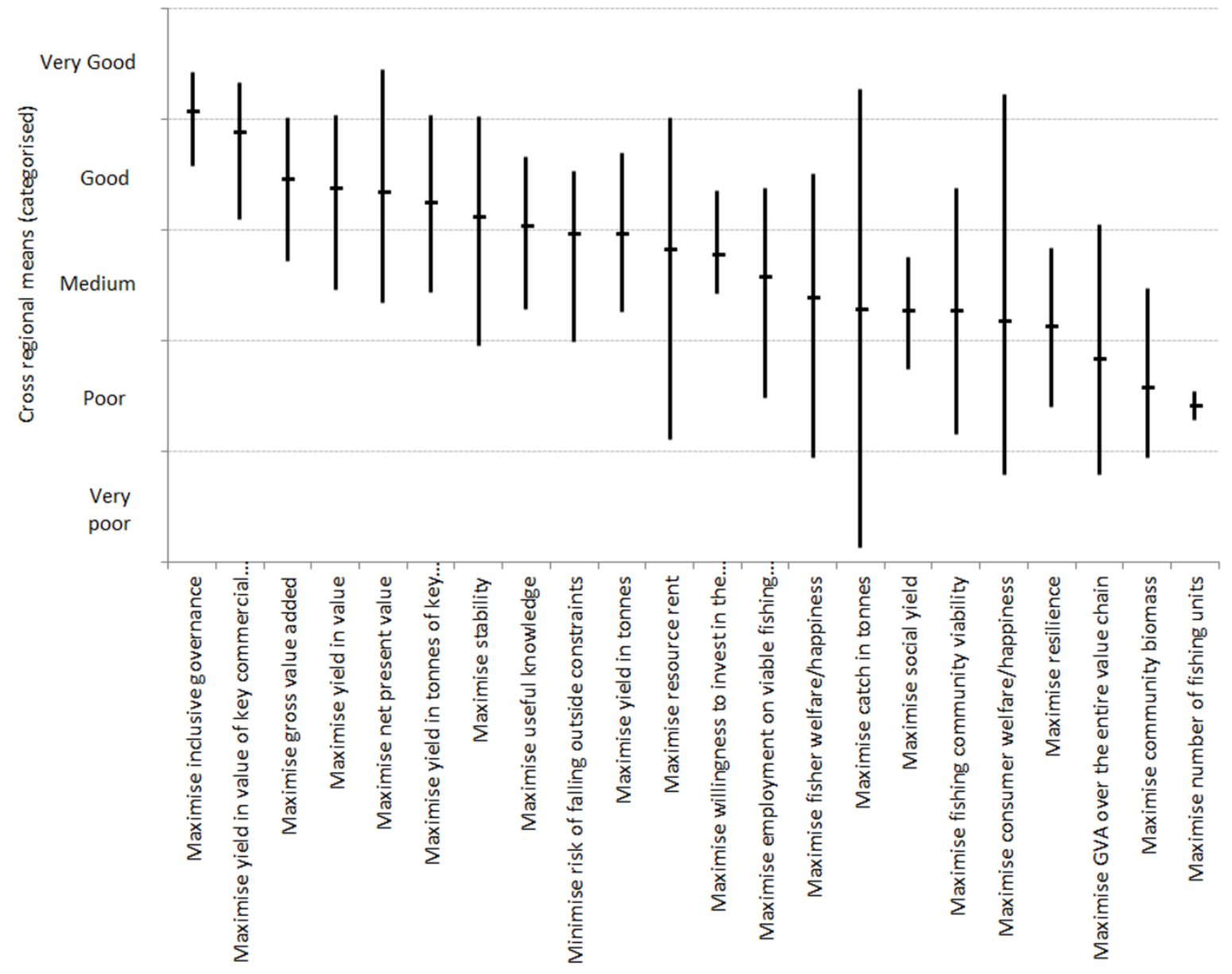

Fig. 2

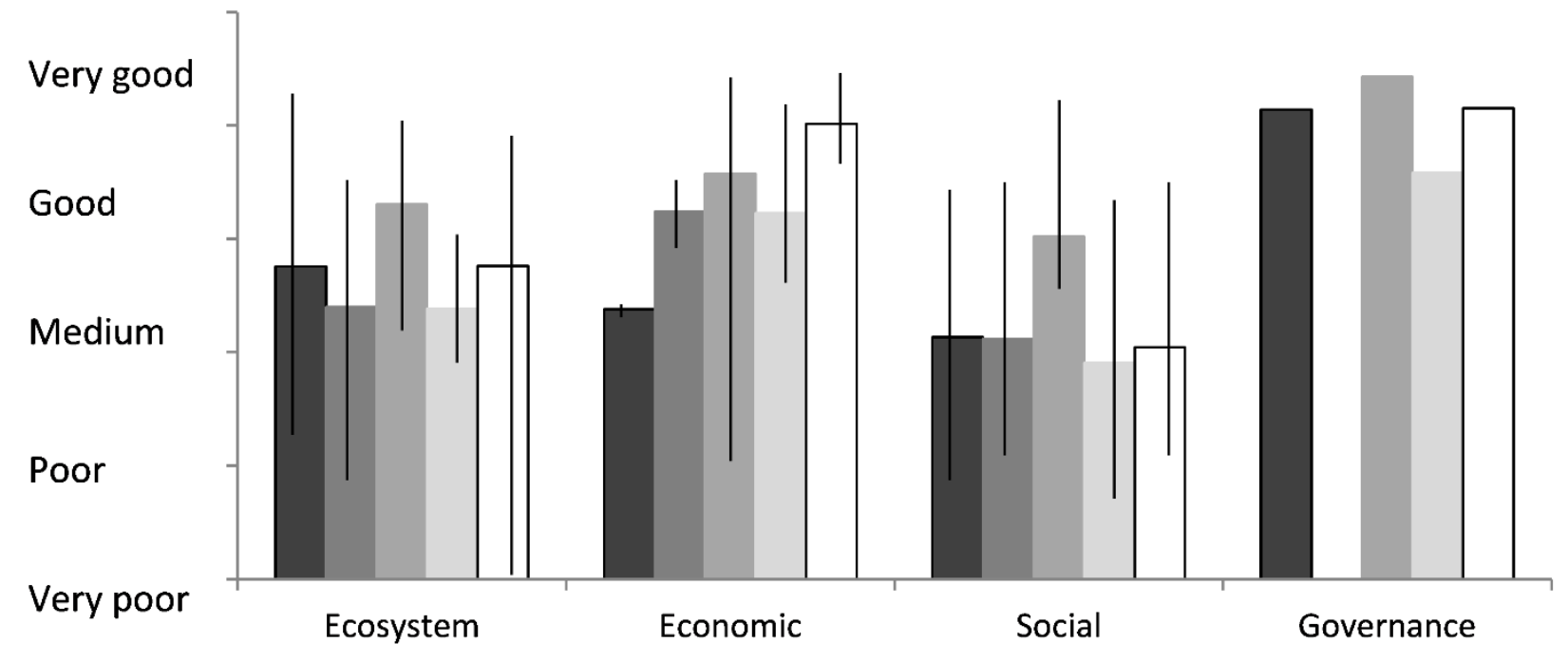

$\square$ Widely ranging stocks $\square$ Baltic Sea $\square$ North Sea $\square$ Western waters $\square$ Mediterranean

Fig. 3 


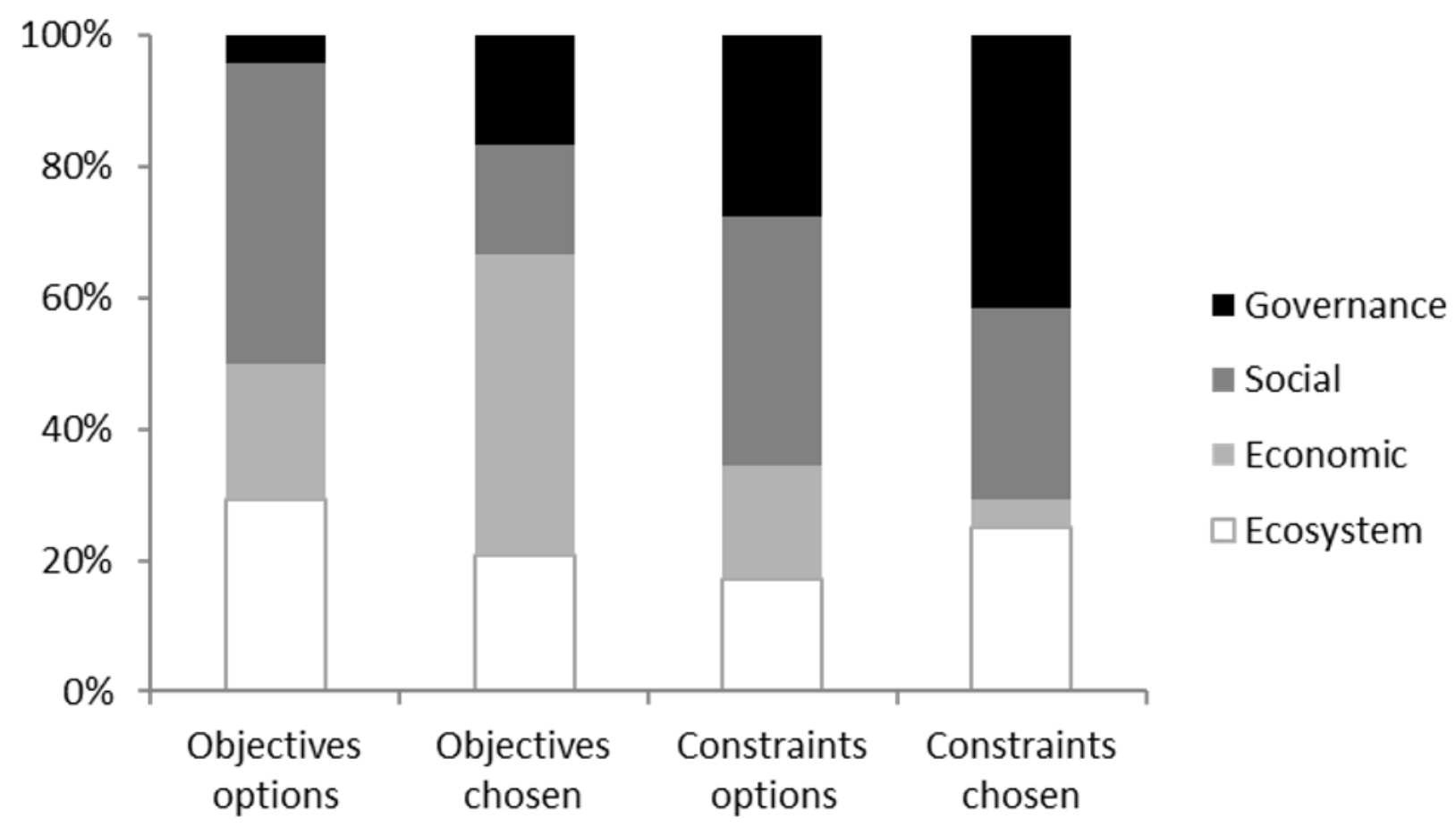

Fig. 4
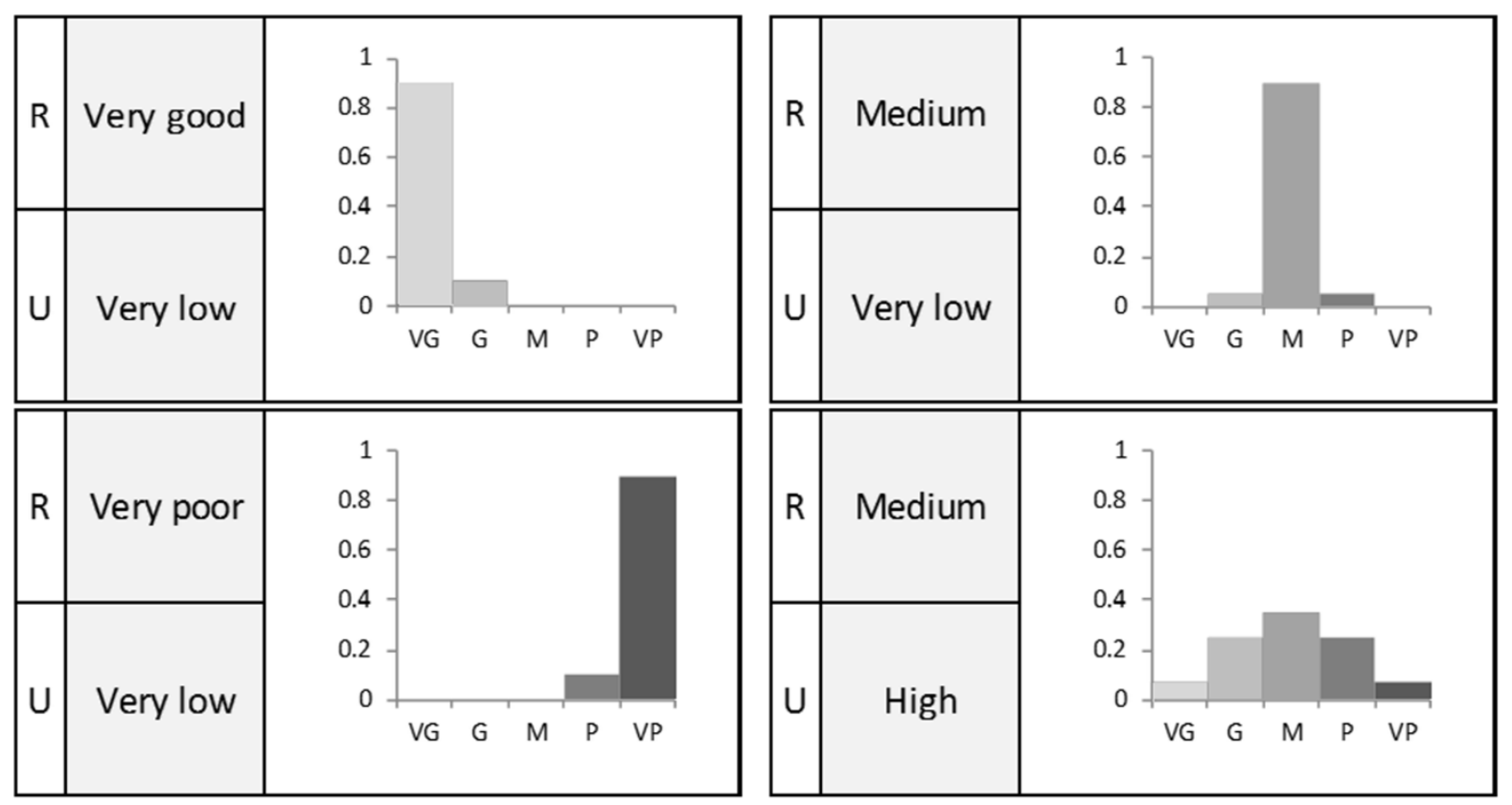

Fig S1 


\begin{tabular}{|c|c|c|}
\hline Option & Category & Explanation \\
\hline Maximise Yield in Tonnes & Ecosystem & $\begin{array}{l}\text { Summed weight of landings of all } \\
\text { commercial species }\end{array}$ \\
\hline $\begin{array}{l}\text { Maximise Yield in Tonnes of Key Commercial } \\
\text { Species }\end{array}$ & Ecosystem & $\begin{array}{l}\text { Summed weight of landings of key } \\
\text { commercial species }\end{array}$ \\
\hline Maximise Catch in Tonnes & Ecosystem & $\begin{array}{l}\text { Summed weight of catch (including discards) } \\
\text { of all commercial species }\end{array}$ \\
\hline $\begin{array}{l}\text { Maximise Present Yield for Human } \\
\text { Consumption }\end{array}$ & Ecosystem & $\begin{array}{l}\text { Summed landings used for human } \\
\text { consumption }\end{array}$ \\
\hline Maximise Stability & Ecosystem & Stability in landings or catches \\
\hline Maximise Community Biomass & Ecosystem & Summed biomass in the ecosystem \\
\hline Minimise Risk of Falling Outside Constraints & Ecosystem & $\begin{array}{l}\text { Constraints are boundaries beyond which } \\
\text { management is considered unsustainable }\end{array}$ \\
\hline Maximise Resilience & Ecosystem & $\begin{array}{l}\text { The ability of the ecosystem to absorb } \\
\text { pressures without creating permanent } \\
\text { distortion }\end{array}$ \\
\hline $\begin{array}{l}\text { Maximise Yield in Value of Key Commercial } \\
\text { Species }\end{array}$ & Economic & $\begin{array}{l}\text { Summed value of landings of key } \\
\text { commercial species }\end{array}$ \\
\hline Maximise Yield in Value & Economic & $\begin{array}{l}\text { Summed value of landings of all commercial } \\
\text { species }\end{array}$ \\
\hline Maximise Gross Value Added & Economic & $\begin{array}{l}\text { Summed value of landings less all variable } \\
\text { costs }\end{array}$ \\
\hline Maximise Resource Rent & Economic & $\begin{array}{l}\text { Summed surplus value less all costs and } \\
\text { normal returns }\end{array}$ \\
\hline Maximise Net Present Value & Economic & $\begin{array}{l}\text { Summed value of landings less all costs } \\
\text { discounted back to its present value }\end{array}$ \\
\hline Maximise Yield/Litre of Fuel or $\mathrm{CO}_{2}$ Emission & Economic & $\begin{array}{l}\text { This objective includes aspects of both MEY } \\
\text { (maximise yield/variable cost) and MSOY } \\
\text { as } \mathrm{CO}_{2} \text { was also suggested as an example } \\
\text { of a societal cost }\end{array}$ \\
\hline Maximise Number of Fishing Units & Social & \\
\hline Maximise Fisher Welfare/Happiness & Social & \\
\hline Maximise Consumer Welfare/Happiness & Social & \\
\hline $\begin{array}{l}\text { Maximise Willingness to Invest in the Future } \\
\text { Fisheries }\end{array}$ & Social & \\
\hline Maximise Social Yield & Social & $\begin{array}{l}\text { Summed value from a societal perspective in } \\
4 \times 4 \text { categories: Utility, Experimental, } \\
\text { Future, Institutional value from a social, } \\
\text { cultural, governance, ecological } \\
\text { perspective }\end{array}$ \\
\hline $\begin{array}{l}\text { Maximise Employment on Viable Fishing } \\
\text { Units }\end{array}$ & Social & Requires a definition of 'viable' \\
\hline $\begin{array}{l}\text { Maximise Gross Value Added over the Entire } \\
\text { Value Chain }\end{array}$ & Social & $\begin{array}{l}\text { Summed value of fish/invertebrate products } \\
\text { less all variable costs in fishing and } \\
\text { processing }\end{array}$ \\
\hline Maximise Fishing Community Viability & Social & Requires a definition of 'viability' \\
\hline Maximise Health Benefit/ $\mathrm{CO}_{2}$ & Social & $\begin{array}{l}\text { Health benefit could be essential fatty acids } \\
\text { and } \mathrm{CO}_{2} \text { was given as an example of a } \\
\text { societal cost }\end{array}$ \\
\hline Maximise Useful Knowledge & Social & \\
\hline Maximise Inclusive Governance & Governance & $\begin{array}{l}\text { Engaging an appropriate range of } \\
\text { stakeholders to influence the decision- } \\
\text { making process. The range of } \\
\text { stakeholders should include all categories } \\
\text { of stakeholders and the process should } \\
\text { be iterative. }\end{array}$ \\
\hline
\end{tabular}




\begin{tabular}{|c|c|}
\hline Option & Category \\
\hline $\begin{array}{l}\text { Indicators of Good Environmental Status of commercial species, biodiversity, food web } \\
\text { functioning and seafloor integrity above reference level }\end{array}$ & Ecosystem \\
\hline $\begin{array}{l}\text { Mortality of potentially endangered and threatened species and other vulnerable species } \\
\text { below specified level }\end{array}$ & Ecosystem \\
\hline Profits above a minimum level & Economic \\
\hline Technical selectivity unaltered & Economic \\
\hline Reduce barriers to mobility in the fishing industry (to join or leave the industry) & Economic \\
\hline Meet certification requirements & Economic \\
\hline Stability of landings & Social \\
\hline Discard of non-target species below specified level & Social \\
\hline Carbon footprint less than specified level & Social \\
\hline Maintain human food supply above specified level & Social \\
\hline Legislation adhered to/compliance above reference levels & Social \\
\hline Maintaining small communities at a specified level & Social \\
\hline Maintaining vessel size distribution at a certain level & Social \\
\hline Human accidents at sea below a specified level & Social \\
\hline Employment above a specified level & Social \\
\hline Equity of income & Social \\
\hline Increase status of fishers & Social \\
\hline Maintain consumer choice for different kinds and sources of fish & Social \\
\hline Management cost below specified level of GVA & Governance \\
\hline Retain subsidies & Governance \\
\hline Maintain trust among industry participants & Governance \\
\hline Increase level of self-determination for fishing actions by fishers & Governance \\
\hline Maintain fishing rights and ownership & Governance \\
\hline Maintain relative stability ${ }^{1}$ & Governance \\
\hline Legislation adhered to/compliance & Governance \\
\hline Areas with fishing restriction (e.g. Natura 2000) & Governance \\
\hline
\end{tabular}


9 these received 'Good' or 'Very good' ratings. Ratings are: < 0.8: Very good; 0.8-1.4: Good.

\begin{tabular}{|c|c|c|c|c|}
\hline Region & Objective & Ranking & Rating & Category \\
\hline Baltic Sea & Minimise Risk of Falling Outside Constraints & 1 & 1.17 & Ecosystem \\
\hline Baltic Sea & Maximise Gross Value Added & 1 & 1.17 & Economic \\
\hline Baltic Sea & Maximise Resource Rent & 1 & 1.17 & Economic \\
\hline Baltic Sea & Maximise Fisher Welfare/Happiness & 3 & 1.19 & Social \\
\hline Mediterranean Sea & Maximise Net Present Value & 1 & 0.44 & Economic \\
\hline Mediterranean Sea & Maximise Inclusive Governance & 2 & 0.68 & Governance \\
\hline Mediterranean Sea & Maximise Gross Value Added & 3 & 0.79 & Economic \\
\hline Mediterranean Sea & Maximise Resource Rent & 3 & 0.79 & Economic \\
\hline Mediterranean Sea & Maximise Yield in Tonnes of Key Commercial Species & 5 & 0.87 & Ecosystem \\
\hline Mediterranean Sea & Maximise Yield in Value of Key Commercial Species & 5 & 0.87 & Economic \\
\hline North Sea & Maximise Inclusive Governance & 1 & 0.46 & Governance \\
\hline North Sea & $\begin{array}{c}\text { Maximise Yield of Fish/Litre of Fuel (or } \mathrm{CO}_{2} \text { Emission) or } \\
\text { similar energy unit }\end{array}$ & 2 & 0.47 & Economic \\
\hline North Sea & Maximise Yield in Value of Key Commercial Species & 3 & 0.53 & Economic \\
\hline North Sea & Maximise Consumer Welfare/Happiness & 4 & 0.62 & Social \\
\hline North Sea & Maximise Yield in Value & 5 & 0.77 & Economic \\
\hline Western Waters & Maximise Yield in Value of Key Commercial Species & 1 & 0.65 & Economic \\
\hline Western Waters & Maximise Yield in Value & 2 & 1.12 & Economic \\
\hline Western Waters & Maximise Inclusive Governance & 3 & 1.14 & Governance \\
\hline Western Waters & Maximise Willingness to Invest in the Future Fisheries & 4 & 1.32 & Social \\
\hline Widely Ranging Stocks & Maximise Catch in Tonnes & 1 & 0.58 & Ecosystem \\
\hline Widely Ranging Stocks & Maximise Inclusive Governance & 2 & 0.69 & Governance \\
\hline Widely Ranging Stocks & Maximise Stability in catches & 3 & 0.92 & Ecosystem \\
\hline Widely Ranging Stocks & Maximise Yield in Tonnes & 4 & 1.04 & Ecosystem \\
\hline Widely Ranging Stocks & Maximise Useful Knowledge & 5 & 1.25 & Social \\
\hline
\end{tabular}




\begin{tabular}{|c|c|c|c|}
\hline Region & Constraint & Ranking & Category \\
\hline Aegean Sea (Mediterranean) & Employment Above a Specified Level & 1 & Social \\
\hline Aegean Sea (Mediterranean) & $\begin{array}{l}\text { GES Descriptors of Commercial Species Above Reference } \\
\text { Level }\end{array}$ & 2 & Ecosystem \\
\hline Aegean Sea (Mediterranean) & Maintaining Small Communities at a Specified Level & 3 & Social \\
\hline Aegean Sea (Mediterranean) & Retain Subsidies & 4 & Governance \\
\hline Aegean Sea (Mediterranean) & Legislation Adhered To/Compliance & 5 & Social \\
\hline Balearic Sea (Mediterranean) & Areas with Fishing Restriction (e.g. Natura 2000) & 1 & Governance \\
\hline Balearic Sea (Mediterranean) & Profits Above a Minimum Level & 2 & Economic \\
\hline Balearic Sea (Mediterranean) & Employment Above a Specified Level & 2 & Social \\
\hline Balearic Sea (Mediterranean) & Retain Subsidies & 2 & Governance \\
\hline Balearic Sea (Mediterranean) & Maintaining Small Communities at a Specified Level & 2 & Social \\
\hline Balearic Sea (Mediterranean) & Stability of Landings & 2 & Social \\
\hline Balearic Sea (Mediterranean) & Maintain Human Food Supply Above Specified Level & 2 & Social \\
\hline North Sea & $\begin{array}{c}\text { GES Descriptors of Commercial Species, Biodiversity, Food } \\
\text { Web Functioning and Seafloor Integrity Above Reference } \\
\text { Level }\end{array}$ & 1 & Ecosystem \\
\hline North Sea & Areas with Fishing Restriction (e.g. Natura 2000) & 1 & Governance \\
\hline North Sea & $\begin{array}{c}\text { Mortality of PET and Other Vulnerable Species Below } \\
\text { Specified Level }\end{array}$ & 1 & Ecosystem \\
\hline North Sea & Discards of Non-target Species Below Specified level & 1 & Ecosystem \\
\hline North Sea & Legislation Adhered To/Compliance & 1 & Governance \\
\hline North Sea & Maintain Relative Stability & 1 & Governance \\
\hline North Sea & Human Accidents at Sea Below a Specified Level & 1 & Social \\
\hline Widely Ranging Stocks & $\begin{array}{c}\text { GES Descriptors of Commercial Species Above Reference } \\
\text { Level }\end{array}$ & 1 & Ecosystem \\
\hline Widely Ranging Stocks & $\begin{array}{c}\text { Mortality of PET and Other Vulnerable Species Below } \\
\text { Specified Level }\end{array}$ & 2 & Ecosystem \\
\hline Widely Ranging Stocks & Areas with Fishing Restriction (e.g. Natura 2000) & 3 & Ecosystem \\
\hline Widely Ranging Stocks & Maintain Trust Among Industry Participants & 4 & Governance \\
\hline Widely Ranging Stocks & Maintain Relative Stability & 5 & Governance \\
\hline
\end{tabular}

13 
17 Table 5. Proportion of objectives in the preferred top five relative to the maximum possible,

18 and the proportionexpected if no selection took place.

\begin{tabular}{|l|c|c|c|c|}
\hline Category & Ecosystem & Economic & Social & Governance \\
\hline Proportion of possible objectives & 0.29 & 0.21 & 0.46 & 0.03 \\
\hline Proportion of rated objectives in top 5 & $\begin{array}{c}0.21 \\
(\mathrm{P}=0.1250)\end{array}$ & $\begin{array}{c}\mathbf{0 . 4 6} \\
(\mathbf{P}=\mathbf{0 . 0 0 4 1 )}\end{array}$ & $\begin{array}{c}\mathbf{0 . 1 7} \\
(\mathbf{P}=\mathbf{0 . 0 0 2 0})\end{array}$ & $\begin{array}{c}\mathbf{1 . 0 0} \\
(\mathbf{P}<\mathbf{0 . 0 0 0 1 )}\end{array}$ \\
\hline Proportion of possible objectives & 0.17 & 0.17 & 0.38 & 0.28 \\
\hline Proportion of rated objectives in top 5* & $\begin{array}{c}0.25 \\
(\mathrm{P}=0.1052)\end{array}$ & $\begin{array}{c}0.04 \\
(\mathrm{P}=0.0639)\end{array}$ & $\begin{array}{c}0.29 \\
(\mathrm{P}=0.2535)\end{array}$ & $\begin{array}{c}\mathbf{0 . 4 2} \\
(\mathbf{P}=\mathbf{0 . 0 4 2 7})\end{array}$ \\
\hline
\end{tabular}

19 'relative to the maximum possible, hence these values do not sum to one, as governance had

20 only one objective and this was only rated by four groups (maximum number of top five

21 entries=4).

22 
Table 6. The objectives and constraints evaluated in regional response workshops.

\begin{tabular}{|c|c|c|}
\hline Region & Objectives and constraints presented & Results \\
\hline Baltic Sea & $\begin{array}{l}\text { Maximise Net Present Value (Economic); Maximise Net Present Value While } \\
\text { Conserving Sprat (Economic with ecosystem constraints); and Maximise Net Present } \\
\text { Value While Conserving Equity between Countries (Economic with social constraints) }\end{array}$ & $\begin{array}{l}\text { The conservation approach (Economic with ecosystem constraints) received the best } \\
\text { average score (Medium) and showed the lowest variation between participants. This } \\
\text { scenario combines aspects of minimise risk and maximises gross value added/resource } \\
\text { rent which were originally rated in top } 5 \text {. However, the differences between the } \\
\text { different scenarios were slight, and no strong preferences were observed. }\end{array}$ \\
\hline $\begin{array}{l}\text { Mediterranean: } \\
\text { Aegean Sea }\end{array}$ & $\begin{array}{l}\text { Current single species MSY (Ecosystem); Maximise Net Present Value (Economic); and } \\
\text { a scenario which went towards MEY but limited the reduction of fleet capacity } \\
\text { (Economic with social constraints) }\end{array}$ & $\begin{array}{l}\text { The preferred scenario was intermediate between single species MSY and MEY. This } \\
\text { scenario combines economic objectives to be maximised (net present value) with } \\
\text { social constraints (limit change in employment) and the need to Maximise Inclusive } \\
\text { Governance, all of which were in the original top } 5 \text {. }\end{array}$ \\
\hline $\begin{array}{l}\text { Mediterranean: } \\
\text { Balearic Sea }\end{array}$ & $\begin{array}{l}\text { Current fishing exploitation scheme; Maximise Net Present Value (Economic); and an } \\
\text { intermediate scenario in between these two extreme situations in which the effort, } \\
\text { catch and economic value are at the average between the current and the predicted } \\
\text { MEY scenarios (Economic with social constraints) }\end{array}$ & $\begin{array}{l}\text { The preferred scenario was intermediate between the current situation and the full } \\
\text { MEY. This intermediate scenario combines the objectives of net present value } \\
\text { (Economic) and Maximise Inclusive Governance (Governance), both of which were in } \\
\text { the original top 5. }\end{array}$ \\
\hline North Sea & $\begin{array}{l}\text { 1. Focus on biological interactions in the context of multispecies MSY in tonnes } \\
\text { (Ecosystem), value (Economic) and multispecies ranges (Ecosystem and } \\
\text { Governance) } \\
\text { 2. Focus on MSY in tonnes (Ecosystem) and net present value (Economic) when } \\
\text { accounting for technical interactions in the fisheries on North Sea gadoids while } \\
\text { implementing single species } F_{M S Y} \text { and a landing obligation } \\
\text { 3. Focus on multispecies MSY in tonnes (Ecosystem) and net present value } \\
\text { (Economic) for flatfish and shrimp fleets in the southern North Sea in an } \\
\text { ecosystem setting }\end{array}$ & $\begin{array}{l}\text { 1. The preferred objective was a qualitative approach to multispecies MSY as this } \\
\text { approach makes it possible to address with trade-offs caused by biological and } \\
\text { technical interactions. The approach combines ecosystem objectives with } \\
\text { governance objectives (Maximise Inclusive Governance) and constraints (adhere } \\
\text { to current legislation on MSY), both of which were in the original top 5. } \\
\text { 2. and 3. The preferred objective was economic objectives (MEY) but concerns about } \\
\text { social consequences (i.e. employment) when aiming for MEY were raised. } \\
\text { All: The preferred scenarios combined economic objectives (Maximise value } \\
\text { landed or Yield per Litre Fuel) and governance objectives (Maximise Inclusive } \\
\text { Governance), all of which were in the original top 5, in solutions where ranges in } \\
\text { acceptable yield allowed room for negotiation. }\end{array}$ \\
\hline Western Waters & $\begin{array}{l}\text { Single stock MSY (Ecosystem) and Maximise Net Present Value of key commercial } \\
\text { species (Economic) combined in scenarios with constant effort in artisanal fleets, as a } \\
\text { proxy for maintaining the employment in these fleets (adding social constraints) }\end{array}$ & $\begin{array}{l}\text { The preferred objectives depended on the stakeholder compositions as } \\
\text { representatives of artisanal fleets preferred to be outside the TAC and quota } \\
\text { management system and maintain their effort regardless of the objective used to } \\
\text { manage the whole fishery. On the other hand, the industrial fleet representatives } \\
\text { preferred Maximise Net Present Value of key commercial species (Economic } \\
\text { objective), and economic objectives were dominant in the original top 5. }\end{array}$ \\
\hline $\begin{array}{l}\text { Widely Ranging } \\
\text { Stocks }\end{array}$ & $\begin{array}{l}\text { Focus on Norwegian Spring Spawning herring, North Sea herring and North Sea sprat. } \\
\text { Results for MSY (Ecosystem), Stability of Catches (Ecosystem) and Good Environmental } \\
\text { Status of the stocks (Ecosystem) for the North Sea. }\end{array}$ & $\begin{array}{l}\text { The objective MSY in tonnes while ensuring stability in catches was preferred by most } \\
\text { participants (Ecosystem objective with ecosystem constraints). This scenario } \\
\text { combined aspects of Maximise Yield in Tonnes, Maximise Stability and Maximise } \\
\text { Inclusive Governance, all of which were in the original top 5. }\end{array}$ \\
\hline
\end{tabular}


